Mehmet Akif Ersoy Üniversitesi Fen Bilimleri Enstitüsü Dergisi 11(2): 150-163 (2020)

The Journal of Graduate School of Natural and Applied Sciences of Mehmet Akif Ersoy University 11(2): 150-163 (2020)

Araştırma Makalesi / Research Paper

\title{
Isparta-İslamköy Örneğinde Arazi Toplulaştırma Çalışmalarının Mekansal Olarak Değerlendirilmesi
}

\author{
Taylan KINALI ${ }^{\mathbb{D} 1}$, Ulvi Erhan EROL (D) ${ }^{*}$, Latif Gürkan KAYA ${ }^{\text {(D) } 3}$ \\ ${ }^{1}$ Doğa Koruma ve Milli Parklar Genel Müdürlüğü, Denizli \\ ${ }^{2}$ Süleyman Demirel Üniversitesi, Mimarlık Fakültesi, Isparta \\ ${ }^{3}$ Burdur Mehmet Akif Ersoy Üniversitesi, Mühendislik-Mimarlık Fakültesi, Burdur \\ Geliş Tarihi (Received): 16.05.2020, Kabul Tarihi (Accepted): 25.07.2020 \\ $\square$ Sorumlu Yazar (Corresponding author*): uerhane@yahoo.com \\ (C) +902462113843 且 +902462118231
}

Öz

Bu çalışmada, Türkiye'de Tarım Reformu Genel Müdürlüğü tarafından yürütülen arazi toplulaştırma çalışmalarının ekolojik temele dayanan planlama yaklaşımı ile gerçekleştirilmesi; alan kullanım seçeneklerini bütünleştirilmesi; ekosistemlerin doğal yapısını bozmadan insanoğlunun yaşamsal faaliyetlerini yürütebilmesi ile optimal alan kullanımlarının belirlenmesine, katkı sağlanması amaçlanmıştır. Çalışma kapsamında, Isparta İslamköy ve yakın çevresinin doğal yapısı, mevcut alan kullanımları ve sosyo-ekonomik yapısı ortaya çıkarılmış; tarım, orman, çayırmera, rekreasyon, yerleşim ve sanayi kullanım türleri için uygun alan kullanımları belirlenmeye çalışıımıştır. Uygunluk analizinin gerçekleştirilmesinde coğrafi bilgi sistemleri (CBS) ve çok kriterli analiz metodu kullanılmıştır. CBS aracılığı ile uygunluk kriterleri, değerleri ve katsayıları sorgulanarak her alan kullanım türü için uygunluk haritaları hazırlanmış, elde edilen uygunluk haritaları birleştirilerek en ideal alan kullanım haritası oluşturulmuştur. Sonuç olarak, İslamköy idari sınırları içerisinde mevcut alan kullanımları, çevre düzeni planı ve en uygun alan kullanım haritası karşılaştırılmış, köy gelişim alanları tespit edilerek blok planı modeli önerilmiştir.

Anahtar Kelimeler: Arazi, doğa, ekoloji, İslamköy, tarım

\section{Spatial Evaluation of Land Consolidation Studies in the Sample of Isparta- Islamkoy, Turkey}

\begin{abstract}
In this study, conducted by the General Directorate of Agricultural Reform land consolidation efforts in Turkey to carry out the planning approach based on ecological basis; integrating field use options; It was aimed to contribute to the determination of optimal use of space by enabling human beings to carry out their vital activities without destroying the natural structure of ecosystems. In this context, the natural structure of Isparta Islamkoy selected as the case area and its environs, existing land uses and socio-economic relating to the structure; agricultural, forest, pasture, recreation, residential, and industrial use to identify appropriate for the types of land uses have been made. The conformity analysis geographical information systems (GIS) and multiple criteria analysis was applied in the realization of a methodology. Through GIS, eligibility criteria, values and coefficients for each land use type maps prepared and would be questioned the suitability, suitability maps obtained by combining the optimal land use map has been created. As a result, the existing land uses and environmental plan with optimal land use map were compared within the boundaries of İslamköy, and the block plan model was proposed by determining the village development areas.
\end{abstract}


Keywords: Land, nature, ecology, İslamköy, agriculture

\section{GíRiş}

Hızlı nüfus artışı ve buna bağlı olarak artan yerleşim alanı, tarım, orman ve su ürünleri çeşitliliği nedeniyle; doğru ve verimli arazi kullanımı ve ekosistem bütünlüğü ile sağlığı büyük bir önem kazanmıştır. Bununla birlikte, Insanoğlu, var olduğundan bu yana artan intiyaçlarını karşılamak ve gittikçe karmaşıklaşan yaşam tarzı içerisinde düzen sağlamak için planlama olgusunu geliştirmiştir. İnsan intiyaçları gözetilerek tüm doğal ve kültürel kaynakların akılcı bir şekilde kullanılması, sürdürülebilirlik ilkeleri çerçevesinde düzenlemelerin yapılması ve en uygun yaşam standartlarının oluşturulmaya çalışılması tüm planlama yaklaşımlarının temel hedefidir. Doğayı ve üzerinde yaşanılan araziyi koruyabilmek, var olan potansiyelden en üst düzeyde ve sürdürülebilirlik çerçevesinde yararlanabilmek, geliştirerek sonraki kuşakların yararlanmasına sunabilmek, birbiri ile çelişmeyen kullanım biçimlerini irdeleyip araştırarak, bir plana dayalı olarak düzenleyerek sürekli bakım ve denetimini sağlayarak mümkün olabilmektedir (Başal, 1998; Durduran ve ark., 2018). Plansız arazi kullanımı sonucunda, birçok ekolojik, ekonomik ve sosyal sorunlar yaşanmaktadır. $\mathrm{Bu}$ durum doğal kaynakların bozulmasına ve sürdürülebilir kalkınmanın tehlikeye girmesine neden olmaktadır.

Bu tür olumsuzlukları önlemek için, araziden faydalanan ormancılık, tarım, mera, yerleşim, sanayi, ulaşım, vb. sektörlerin mevcut çalışma alanlarının biyofiziksel, sosyal, ekonomik, kültürel ve çevresel değişkenlere bağlı olarak kesin bir şekilde belirlenip bir arazi kullanım planına ve haritasına bağlanmasına intiyaç bulunmaktadır. Kırsal alanlardaki konuya yaklaşırken, buralarda yaşayan halkın büyük ölçüde orman, tarım ve mera arazilernden elde edilen çeşitli ürün ve hizmetlere bağlı olarak yaşadığı görülmektedir (Bozdoğan ve ark., 2016; Durduran ve ark., 2018). Bu nedenle kırsal alanlardaki orman, tarım ve mera arazilerinin en uygun mekansal tahsisini gerçekleştiren planların yapılması ve bu planlara göre yönetilmesinin sağlanması önemlidir. Ancak bu şekilde arazi kaynaklarını etkin ve verimli kullanarak kırsal kalkınmaya katkı sağlanmaktadır (Yılmaz, 2006; Durduran ve ark., 2018). Kırsal alan yeni yapılanmalar için bir rezerv alanıdır. Yeni yerleşim ve sanayibölgelerinin oluşturulmasında, yeni yolların, hava alanlarının, barajların vebenzeri kalkınma yapılarının oluşturulmasında gerekli arazilerin sağlanması çokyönlü bir kırsal alan düzenlemesiyle olasıdır. Dolayısıyla, uzun bir yasal süreci ve ağır bir ekonomik yükü olan kamulaştırma gibi bir yönteme başvurmaya gerek yoktur. Bu bağlamda, proje bölgesi olarak seçilen bölge ile ilgili kurum ve kuruluşların çeşitli planlama taleplerini toplamak, karşılıklı dengelenmek ve olumsuzlukları gidermek için önlemler almak amacıyla arazi toplulaştırması yapılmaktadır (Auweck,1993; Bozdoğan ve ark. 2016; Durduran ve ark., 2018). Türkiye'nin kalkınmasında önemli rol oynayan karayolları, demiryolları, havaalanları, barajlar, madenler, sanayi sahaları, okullar, turizm tesisleri, sulama ve drenaj kanalları vb. kamu yatırımlarında kullanılmak üzere, gerekli olan arazilerin karşılanmasında ve söz konusu tesislere yatırım maliyetlerinin azaltılmasında arazi toplulaştırma çalışmaları oldukça önemlidir. Bu nedenle, T.C.Gıda Tarım ve Hayvancılık Bakanlığı, Tarım Reformu Genel Müdürlüğü (TRGM) tarafından yürütülen hizmetler olan arazi kullanım planlaması, köy gelişim alanlarının tespiti ve yeni yerleşim yerlerine ait imar planı çalışmaları, çiftçi eğitimi ve arazi toplulaştırma çalışmalarının birlikte ele alınması gereklidir.

Uydu verileri ve en son hesaplama teknolojileri kullanılarak yapılan çalışmaya göre Türkiye'de toplulaştırması yapılabilecek arazi miktarı 14 milyon ha olarak hesaplanmıştır. Bunun 8,5 milyon ha sulu ve 5,5milyon ha da kuru alanlar oluşturmaktadır (Sönmezyıldız, 2012). Gerek Türkiye'de ve gerekse diğer ülkelerde gerçekleştirilen ve potansiyel toplulaştırma çalışmalarının belirli bir plan içerisinde gerçekleştirilmesi zorunluluğunu ortaya çıkmaktadır. Planlama genel anlamda geleceğe yönelik bir kestirim ve karar verme sürecidir. Bu aşamada planlama süreci kavramı ortaya çıkmaktadır. Planlama süreci, problemi belirlenen amaç ve hedefler doğrultusunda çözüme götürmek için, bilgilenme aşamasından, uygulama aşamasına kadar gelişen bir akış içinde olayı izlemek demektir (Tozar, 2006). Bu planlama objelerinden biride "Ekolojik planlama"dır. Ekolojik planlama; henüz yerleşilmemiş, yapılaşmanın olmadığı alanlarda arazi kullanımı kararları verilirken kullanımlar için en uygun yerlerin belirlenmesinde, alana ait elverişli kısıtlayıcı koşulları belirleyen biyofiziksel ve sosyo-kültürel verilerin kullanıldığı bir planlama sürecidir. McHarg (1971) bu süreci aşağıdaki şekilde özetlemiştir (Steiner, 1999);

"Doğadaki bütün sistemler hayatta kalma ve başarılı olmayı amaçlar, hayatta kalmanın göstergesi doğal sistemlerdeki Düzen-Uyum-Sağlık'tır. Bu koşulları sağlamak için sistemlerin en uygun ortamda bulunmaları ve bulundukları yere uyum sağlamaları gerekir. Bir çevrenin bir sistem için uygunluğu, en az seviyede işleyiş ve uyumunu gerektirir. Bunun yanısıra çevrenin alan kullanımına uygunluğu insan sağlığı, yaşam kalitesinin yükseltilmesi ve sağlıklı ortamların oluşumu için önemli bir unsurdur. Bundan dolayı ekolojik planlamada potansiyel arazi 
kullanımları için en uygun alanların belirlenmesi temel amaçtır."

Doğal kaynakların ve ekolojik dengenin sürdürülebilirliğini sağlamak ekolojik planlama yaklaşımının temelini oluşturmaktadır. Fiziksel planlamalarda, arazi kullanım kararları verilirken en uygun yerlerin belirlenmesinde, alana ait elverişli ve kısıtlayıcı koşulları belirleyen biyofiziksel ve sosyokültürel faktörlerin ve aralarındaki ilişkilerin değerlendirildiği planlama süreci ekolojik planlamadır. Ekolojik planlama en etkin doğa koruma aracı olup sürdürülebilir gelişim kalkınmaya temel oluşturmaktadır. Ekolojik planlama ile insan ihtiyaçları karşılanırken aynı zamanda doğal kaynakların en uygun ve sürdürülebilir kullanımlarını ve ekolojik dengelerin devamlılığının sağlanması amaçlanmaktadır (Tozar, 2006). Bu planlamalarda, Peyzaj Uygunluk Yaklaşımı I (LSA-I), bir alan kullanımı için, verilen arazi parçasının uygunluğunu belirlemede doğal peyzaj karakterlerini kullanır. Ekolojik planlamalarda en çok kullanılan PUY-I yöntemleri; Gestalt Yöntemi, Arazi Yetenek Sistemi, Fizyografik Birim Yöntemi, Kaynak Örneği Yöntemi ve Uygunluk Yöntemi'dir (Tozar, 2006).

$\mathrm{Bu}$ bilgiler ışığında, araştırma alanı olarak seçilen İslamköy ve yakın çevresinde, en uygun alan kullanımlarının, ekolojik temele dayanan bir planlama yaklaşımıyla saptanması, önerilen alanlar ile mevcut alan kullanımları arasındaki çelişkileri en aza indirgeyecek önerilerin ortaya konması ve oluşturulan optimal alan kullanım haritası yardımıyla, İslamköy idari sınırlarında öneriler geliştirilmesi amaçlanmıştır.

\section{MATERYAL VE YÖNTEM}

\section{Materyal}

Araştırma alanı alanı olarak seçilen İslamköy ve yakın çevresi; Akdeniz Bölgesi'ndei çkesiminde yeralan Göller Yöresi'nin iki büyük yerleşim merkezlerinde nbiri olan Isparta ili sınırlarıi çerisinde yeralmaktadır. Araştırma alanı $37^{\circ} 52^{\prime}$ ve $38^{\circ} 00^{\prime}$ Kuzey paralelleri ile $30^{\circ} 37^{\prime}$ ve $30^{\circ} 44^{\prime}$ Doğu meridyenleri içerisinde yer alan 15250 ha alanı kapsamakta olup Atabey ilçe merkezi, İslamköy beldesi, Kapıçakköyü, Pembeliköyü, Harmanören köyü ve Büyükgökçeli belde merkezini içerisine almaktadır (Şeki1). Kuzeydoğusu'nda Batı Torosların bir kolu olan Gelincik Dağı, Güneydoğusunda Davraz Dağı ile çevrelenmiştir. Araştırma alanının Kuzey'inde Senirkent, Batı'sında Gönen, Doğu'sunda Eğirdir, Güney'inde ise Isparta merkez ilçeye bağlı Büyükgökçeli ve Kuleönü beldeleri yer almaktadır.

Çalışmamızda, İslamköy ve yakın çevresinin fiziksel yapısı ve ekolojik verileri araştırmanın ana materyalini oluşturmaktadır. Bununla birlikte, araştırma alanının doğal ve kültürel özellikleri, topografik yapı, eğim durumu, bakı durumu, jeolojik yapı, hidrolojik yapı, toprak yapısı, iklim, doğal bitki örtüsü ve mevcut alan kullanımlarına yer verilmiştir.

Araştırma alanında yükselti, Kuzey ve Kuzeydoğu yönüne doğru artmaktadır. Bu yükseltiler Kuzey yönünde Seremet Tepesi'nde 1885 m'ye ulaşır. Bu tepenin Güneybatı yönünde 1879 m kotundaki Canavar Tepesi ve 1824 m kotundaki Kocakır Tepesi, Güney yönünde $1872 \mathrm{~m}$ kotunda Gölgelibaşı Tepesi önemli yükseltilerdir. Araştırma alanının denizden yüksekliği $925 \mathrm{~m}$ ile $1885 \mathrm{~m}$ arasında değişmekte olup ortalama yükseltisi 1150 m'dir. Araştırma alanı, yükselti gruplarına ayrılarak incelendiğinde 900 m ile 1900 m yükseklikler arasında 10 farklı yükseklik kademesi oluşmaktadır. Atabey ve İslamköy ovasından yamaçlara doğru eğim $\%$ 0-37 arasında giderek artan dalgalı ve sarp bir topografya ile çalışma alanı sınırlarına ulaşmaktadır. 


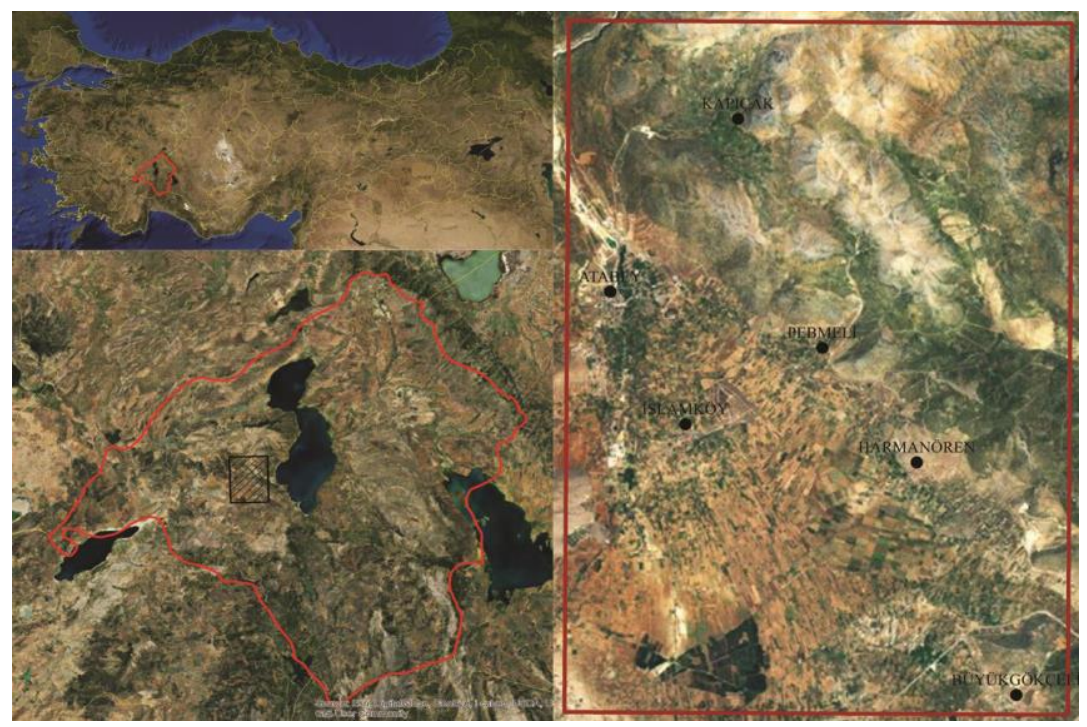

Şekil 1. Çalışma alanının konumu

Araştırma alanının jeolojik yapısı ve fay hatlarını belirlemek amacıyla Maden Tetkik ve Arama(MTA) Genel Müdürlüğü'nün 1997 yılına ait 1/100000 ölçekli jeoloji haritaları sayısallaştırımıştır. Isparta merkezinin kuzeyinde yer alan ve çalışma alanının içerisinde bulunduğu Atabey ilçesi, jeolojik olarak diğer ilçelere göre daha genç bir zemin üzerinde yer almaktadır. Beydağları formasyonunun hakim olduğu çalışma sahasının güneyinde, en üstte gevşek tutturulmuş kil, kum ve çakıl depolarından oluşan Kuvaterner yaşlı alüvyonlar 6268 ha alan ile proje sahasında \%40 oranında yer tutmaktadır. Çalışma alanının yer aldığı sahada yapılan çalışmalar sonucu esas olarak dört farklı fizyografik ünite tespit edilmiştir. Bunlar; kireç taşından oluşan yüksek araziler, koluviyal etek araziler, alüviyal yelpazeler ve alüviyal ovalardır. Kireç taşından oluşan yüksek araziler; çalışma alanının kuzeyinde ve kuzeydoğusunda yer alan çok dik ve sarp eğimli yükseltilerdir. Erozyon nedeni ile yüzeylerinde toprak derinliği çok azdır (Başyiğit, 1996).

Hidrolojik yapının belirlenmesinde Devlet Su İşleri (DSi)Genel Müdürlüğünden araştırma alanına ilişkin yüzey ve yeraltı suyu varlığına ait veriler kullanılmıştır. Araştırma alanı içerisinde Akçay deresi en önemli doğal su kaynağı ve drenaj elemanıdır. Ayrıca Şamlı deresi, Devekayağı deresi, Balıklı deresi, Katran deresi, Medini deresi, Balçıkça deresi ve küçük birçok dere araştırma alanının doğal drenaj paternini oluşturmaktadır. Araştırma alanının yakın çevresinde tarımsal sulama amacı ile 1989 yılında inşaatına başlanarak 1993 yılında inşası bitirilen ve halihazırda faal olarak kullanılan Atabey göleti bulunmaktadır. Kısıkdere akarsuyundan beslenen Atabey göletinin $3,2 \mathrm{hm}^{3}$ su depolama alanı vardır.
Proje sahasından bulunan DSI'nin yapmış olduğu elektropompaj sistemli, $6 \mathrm{~m}$ genişliğindeki sulama kanalı Atabey göletinden beslenmektedir. Bu kanal ve kanaldan beslenen kanaletler yardımı ile Atabey ovasında toplam 14.000 ha alanda tarımsal sulama gerçekleştirilmektedir.

Çalışma alanının toprak özelliğine ilişkin bilgiler Mülga Köy Hizmetleri Genel Müdürlüğü (KHGM)tarafından 1994 tarihinde hazırlanan Isparta İli Arazi Varlığı Raporu'ndan elde edilen 1/25000 ölçekli toprak envanter haritalarından elde edilmiştir. Arazi yetenek sınıflamasında; profil gelişimi, bünye, toprak derinliği, renk-drenaj koşulları, pH doygunluğu, A horizonu gelişimi faktörleri kullanıımaktadır. Çalışma alanı içerisinde bulunan topraklar I, II, III, IV, VI, VII. sınıf yetenekteki topraklardan oluşmakta olup, V, VII. sınıf topraklar araştırma alanında bulunmamaktadır ve araştırma alanında 6 toprak yetenek sınıfı yer almaktadır. Araştırmada elde edilen sonuçlara göre alanda I ve VII. sınıf topraklar en geniş yayılıma sahiptir. Tarım yapmaya uygun olarak belirlenen I ve II. sınıf topraklar araştırma alanı için \%39,6'lık bir yüzde oluşturmaktadır. Araştırma alanında yer alan toprak yetenek sınıflarından en fazla oranda VII. sınıf $(\% 43,3)$ ve I. sınıf araziler $(\% 29,7)$ yer alırken en az oranda IV. sınıf araziler $(\% 0,5)$ yer almaktadır.

Isparta ilinin doğal bitki örtüsü iklim değişikliklerine göre farklılıklar göstermektedir. Isparta'da 1500 m yüksekliğe kadar olan bölgelerede maki türleri ve meşe ağaçlarının yoğunlukta bulunduğu yapraklı ormanlar bulunmaktadır. $2500 \mathrm{~m}$ yüksekliğe ulaştığı yerlerde kızılçam (Pinus brutia), karaçam ( $P$. nigra), sedir (Cedrus libani) ve ardıç (Juniperus sp.) gibi ibreli ağaçlardan oluşan iğne yapraklı ormanlar kaplamaktadır. Isparta ili topraklarının $\% 40$ 'a yakını orman ve fundalıklardan, \%20'si çayır ve 
meralardan, \%16'sı ekili ve dikili arazilerden, \%24'ü ise tarıma elverişsiz arazilerden oluşmaktadır. Araştırma alanı içerisinde yer alan faunanın belirlenmesinde alan ile ilgili yapılmış daha önceki çalışmalar ile yöre halkı ve arazi gözlemlerinden sonuçlara ulaşılmıştır. Araştırma alanında ki fauna memeliler (Mammalia), kuşlar (Aves), sürüngenler (Reptilia) ve ikiyaşamlılar (Amphibia) olarak dört sınıfta incelenmiştir.

Isparta yöresi kış aylarında İzlanda alçak basıncının Balkanlar üzerinden ve Orta Akdeniz'e inerek ılımanlaşmış şeklinde etkilenir. Kış aylarında kuru soğukların sebebi olan Sibirya yüksek basıncı zaman zaman bölgeye kadar sokulmaktadır. Ayrıca kış aylarında geçiş dönemlerinde Kuzey Afrika ülkelerinden gelen tropikal hava kütlelerinin etkisi gözlenir. Isparta ili uzun süreli gözlemlerin klimatolojik olarak incelenmesi sonucunda, Akdeniz iklimi ile Orta Anadolu'da yaşanan karasal iklim arasında geçiş bölgesinde yer almaktadır. Bu nedenle Akdeniz kıyılarında görülen sıcaklık ve yağış özellikleri ile karasal iklimin düşük sıcaklık ve düşük yağış özellikleri tam olarak gözlenemez.

Araştırma alanındaki mevcut alan kullanımları yerleşim, orman, rekreasyon, tarım alanları başlıkları altında incelenerek hava fotoğrafları ve uydu görüntüleri yardımıyla sınıflanmıştır. Araştırma alanındaki mevcut alan kullanımlarından orman alanları 5058 ha $(\% 33,1)$ ve tarım alanları 4390,8 ha $(\% 28,7)$ en fazla alanı kaplayan kullanım tiplerini oluşturmaktadır. Yerleşim 353,5 ha $(\% 2,3)$ ve rekreasyon 17,4 ha $(\% 1,1)$ alanları ise en düşük oranda yer kaplayan alanlardır.

Araştırma alanı içinde Isparta iline bağlı 1 ilçe (Atabey), 2 belde (İslamköy, Büyükgökçeli) ve bunlara bağlı 3 köy yerleşimi (Harmanören, Penbeli, Kapıçak) bulunmaktadır. Nüfus ve gelişmişlik bakımından en büyük yerleşim merkezi Atabey ilçesidir. İ merkezine $23 \mathrm{~km}$ uzaklıkta bulunan Atabey'in kuzeyinde Senirkent, doğusunda Eğirdir, batısında Gönen ilçeleri ile güneyinde Isparta il merkezi bulunmaktadır (Isparta Valiliği, 2020). 2019 yılı nüfus sayımına göre araştırma alanı içerisinde ilçe merkezinde 4375, köy ve beldelerde 1386 olmak üzere toplam 5761 kişi yaşamaktadır (URL-1, 2020).

Atabey ilçesinin yüzölçümü 202 km²dir. İlçe topraklarının kuzey ve batısında Barla Dağı, güneyinde Bozanönü Ovası yer alır. İlçe genelinde tarım birinci sektör konumundadır (Isparta Valiliği, 2020). Ayrıca gül yetiştiriciliği ve gül yağcıı̆ğı, el tezgahlarında yapılan halıcılık ilçe ekonomisine katkı sağlamaktadır. İplik fabrikası başlıca sanayi kuruluşudur. İlçe merkezi denizden 1000 m yükseklikte Barla Dağı eteklerinde kurulmuştur. Eski adı Agros'tur. Tarihi çok eskilere dayanır. 1921'de Büyük Millet Meclisi kararıyla Atabey ismini almıştır ve 1910 'da ilçe belediyesi kurulmuştur. İlçenin son imar planı 1995'te revize edilmiştir.

Çalışma alanı içinde yer alan tarım alanlarının yüksek rakımda bulunmaları, mevsimler arası ve gece-gündüz sıcaklık farklılıklarının fazla olması, vejetasyon periyodunun kısa oluşu gibi ekolojik nedenlerden dolayı tarımda fazla bir ürün çeşitliliği gözlenmemektedir. 1970 yılına kadar kuru tarımın hakim olduğu araştırma alanında 1971 yılında DSi tarafından tamamlanan, Isparta Ovası'nın büyük bir bölümünde sulu tarım yapılabilmesine imkân sağlayan (Bedre, Harmanören, Büyükgökçeli, Küçükgökçeli, Atabey, Gönen, Keçiborlu ovaları) sulama kanalının tamamlanmasıyla sulu tarım ve bahçecilik hızla gelişim göstermiştir. Araştırma alanında ağırlıklı olarak hububat, şeker pancarı, gül yetiştiriciliği ve meyvecilik yapılmaktadır (URL-2, 2014). Atabey ilçesi 8479 ha tarım arazisine sahiptir. 1061 ha alanda bahçecilik yapılmakta iken 2526 ha alanda tarla ziraatı yapılmaktadır. 771 ha alanda sebzecilik, 1420 ha alan nadas olarak kullanılmaktadır. İlçede toplam 2600 dekar kiraz bahçesi mevcuttur. Meyve veren ağaç sayısı 26.500 adettir. Yıllık kiraz üretimi 1325 tondur, bunun 1100 tonu 0900 ziraat kirazı olup tamamına yakını ihraç edilmektedir. Ayrıca 30 dekar alanda kekik yetiştiriciliği de yapılmaktadır (URL-3, 2014). İlçede toplam 6050 dekar alan elma bahçesi olup tamamına yakını starking ve golden çeşitleridir. Meyve veren ağaç sayısı 98.000 adettir, yıllık elma üretimi 24.010 tondur. Son yıllarda bodur türler yaygınlaşmıştır (URL-2, 2014). Araştırma alanında alüviyal topraklara uyum sağlamış olan yem bitkilerinden; yem kaynaşı (Phalaris arundinacea), domuz ayrığı (Dactylis glomerata, D.hispaic), stipa, çayır kelp kuyruğu (Pheleumpratense), otlak ayrığı (Agropyrum cristatum), kır ayrığı (Agropyrum desertorum), yüksek otlak ayrı̆̆ı (Agropyrum elengatum) bulunmaktadır. Kültür bitkisi olarak nohut, fasulye; endüstri bitkisi olarak ayçiçeği, yağ gülü; tahıllardan mısır, arpa ve buğday; meyvelerden elma, kiraz ve üzüm; sebzelerden ise soğan ve marul yoğun olarak yetiştirilmektedir (Başyiğit, 1996).

Araştırma alanındaki ilçe, belde ve köylerde daha çok küçükbaş hayvan yetiştirilmekte onu sırasıyla büyükbaş ve kanatı ıayvan yetiştiriciliği izlemektedir. Dağ köyü olan Kapıçak'ta tarıma elverişli alanların az olması nedeniyle hayvancılık faaliyetleri köy ekonomisinin temelini oluşturmaktadır. İl Tarım Müdürlüğü üreticilere 1500 adet etlik civciv dağıtımı yapmıştır. Ayrıca Sosyal Yardımlaşma ve Dayanışma Vakfı'nca 1150 adet hindi palazı getirilmiştir. Aşılama ve bakımları İlçe Tarım Müdürlüğü veterinerleri tarafından yapılmaktadır.

Araştırma alanının toplam yüz ölçümünün \%58,7'si (8970 ha) orman ve fundalık alanlardan oluşmaktadır. Orman alanı toplam alanın \%33,1'lik bölümünü yani 
5058 ha'lık bir alanı olarak hesaplanabilir. Atabey ilçesine bağlı ve araştırma alanı sınırları içinde bulunan Harmanören, Penbeli ve Kapıçak köyleri orman köyü sınıfındadır.

Arkeolojik ve kültürel değer olarak; Agrae kenti; araştırma alanı sınırları içinde yer alan Atabey ilçe merkezi yakınlarında yer alan Agrae kenti bugünkü ilçe merkezi altında kalmıştır. Birkaç mimari parça haricinde kentten herhangi bir kalıntı bulunmamaktadır. İlçe merkezinin kuzeybatısında Kapıçak köyü yakınında Parlais (Barla) ve Prostanna (Eğirdir) şehirlerinin sınırlarını belirleyen bir sınır yazıtı bulunmaktadır. Agrae, Bizans döneminde Seleukeia ile birlikte bir piskoposluk merkezi konumundadır.

Göndürle Höyük Mezarlığı; Harmanören (Göndürle) köyü yakınındaki Göndürle Höyük Mezarlığı tespit edilmiş ve 1989 yılından bu yana kurtarma kazıları yapılmaktadır. Bu kazı aynı zamanda Isparta ilinde açığa çıkarılan ilk Tunç Çağı mezarlığıdır. Mezarlık alanındaki esas ölü gömme yöntemi küp mezarlar olup ilk Tunç
Çağı ile Orta Tunç Çağı arasında (MÖ 2700/26001900/1800) gömü yapılmıştır. Ölünün yanına mezar hediyesi olarak kadın ise bronz yüzük, küpe, bilezik, ağırşak, gaga ağızı testi vb. kap kacak konulamtadır. Ölen kişi erkek ise taş balta, obsidyen (Doğal cam kesici), bronz spatula vb. metal objelerle, gaga ağızlı testiler konulmaktadır. Söz konusu bu mezarlık alanı Erken Tunç Çağı kültürüne ışık tutmaktadır. Kelian; Araştırma alanında yer alan Kapıçak köyü içinde Kelian isimli bir yerleşim tespit edilmiştir. Kalıntıların mevcut durumuna göre küçük bir yerleşim birimi olan Kelian, Antik Çağda Seleukeia (Bayat) ve Agrae (Atabey)'in bir köyü olduğu düşünülmektedir.

\section{Yöntem}

Araştırmada yöntem olarak, konu ile ilgili Ortaçeşme (1996) ve Konaklı (2011)'nın yaptığı çalışmalar ve yurtdışında benzer amaçlarla daha önce yapılımış çalışmaların yöntemlerinin araştırma alanı koşullarına uygun olarak yorumlanması ile geliştirilmiş bir yöntem olup birbiriyle ilişkili dört bölümden oluşmaktadır (Şekil 2).

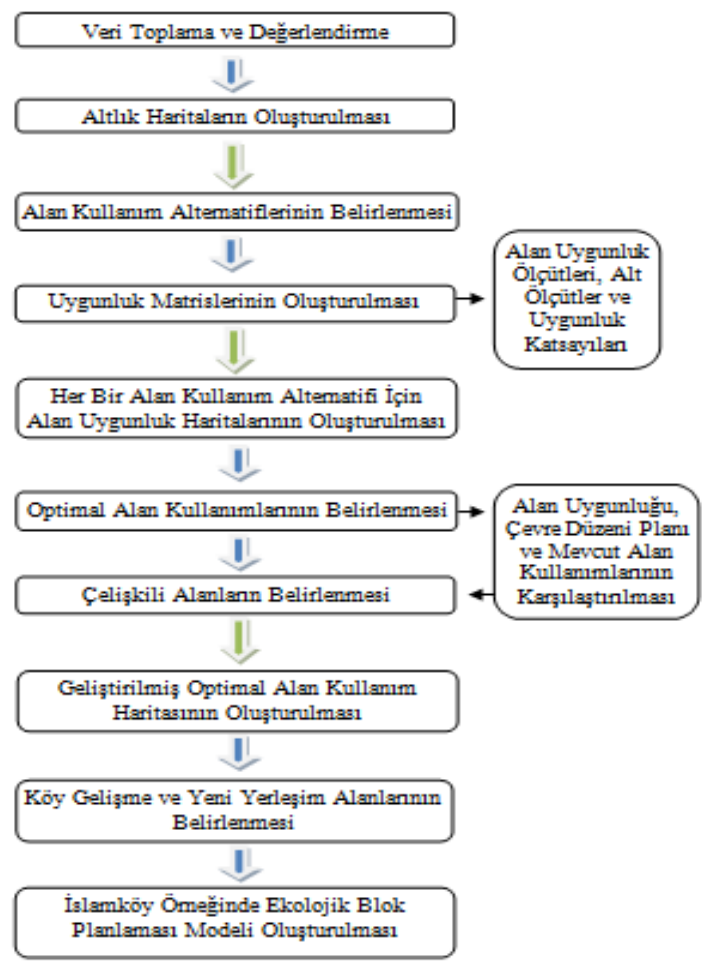

Şekil 2. Yöntem akış şeması 
Bu şema ışığında, çalışmanın birinci bölümü; mevcut verilerin toplanması ve değerlendirilmesi ile altlık haritaların oluşturulması aşamasını içermektedir. Altlık haritaların oluşturulmasında, alana ait doğal ve kültürel peyzaj özelliklerini kapsayan veriler ArcGIS 10.1 programı ile sayısallaştııılmış olup topografik, jeolojik, hidrolojik, toprak ve ulaşım analizleri gerçekleştirilerek uygunluk haritaları için altıklar oluşturulmuştur. Harita Genel Komutanlığı tarafından hazırlanan 1/25.000 ölçekli topografik haritaların eş yükselti eğrileri kullanılarak yüzeyin yükselti yapısını net bir biçimde ortaya koyan alana ait "Sayısal Yükseklik Modeli" görüntüleri üretilmiştir. Oluşturulan sayısal yükseklik modeli, yükseklik grupları, eğim ve bakı haritalarının üretilmesinde kullanılmıştır. Ayrıca eldeedilen veriler uygun koordinatlara getirilerek birbirleri ile uyumu sağlanmıştır.

İkinci bölümde; alan kullanım alternatiflerin belirlenmesi ve uygunluk matrislerinin oluşturulması aşamalarını kapsamaktadır. Alan uygunluk matrislerinin oluşturulmasında "Çok Kriterli Analiz" (MCA) yöntemi kullanıımıştır ve çok kriterli alan uygunluk değerlendirmeleri kapsamında öncelikle araştırma alanının potansiyel alan kullanım şekilleri olarak kabul edilen tarım, çayır-mera, orman, yerleşim, rekreasyon ve sanayi kullanımlarının her birisi üzerinde alan uygunluk değerlendirmelerinde etkili olabilecek ölçütler, bunlara ait alt ölçütler ve uygunluk katsayıları ortaya konmuştur. Bu alan kullanımları için alan uygunluk matrislerinin oluşturulmasında belirleyici olabilecek ölçütler, alt ölçütler ve uygunluk katsayıları seçilirken, daha önce konu ile ilişkili yapılan çalışmalar dikkate alınmıştır. Bunun yanı sıra bu yöntemin uygulanabilirliği için CBS tekniklerinden yararlanılmıştır. Bu aşamada ölçüt ve alt ölçüt olarak; toprak yetenek sınıfları, jeolojik yapı, bitki örtüsü, yükselti grupları, bakı, su varlığına uzaklık, ulaşım belirlenmiştir. Saptanan bu ölçütler, kullanım potansiyelini belirlemedeki etkinlikleri yönünden 4'lü Likert ölçeği ile değerlendirilmiştir. Bu amaçla Ortaçeşme (1996), Yılmaz (2006) ve Konaklı (2011)'nın yaptığı çalışmalar temel alınmıştır. Bu yöntemin uygulanmasında CBS tekniklerinden yararlanılmıştır. Potansiyel alan kullanımlarını belirlemek için, değerlendirme ölçütleri alt birimlerine 1 ile 4 arasında değişen sayısal değerler verilerek uygunluk değerleri oluşturulmuştur. Bu değerlendirmede; 4-Çok Uygun, 3-Uygun, 2Az Uygun, 1-Uygun Değil şeklinde sıralanmaktadır. Ancak alan uygunluk ölçütüne ait alt ölçüt sayısının 4 adetten az olduğu durumlarda bu sıra gözetilmeksizin öznel bir değerlendirme ile puanlandırma yapılmıştır. Alan uygunluk ölçütlerinin uygunluk katsayıları (UK) daha önce yapılan çalışmalardan elde edilen bilgiler doğrultusunda saptanmış ve buna göre alternatiflerin önem ağırlıkları hesaplanarak bir alternatifin diğerine göre tercih edilme olasılığı bulunmuştur. Yönteminüçüncü bölümü; alan uygunluk haritalarının (1/25.000 ölçekli haritalar 30x30 m'lik plankarelere ayrılması) oluşturulması (Patrono,
1998), en uygun alan uygunluklarının belirlenmesi, çelişki alanlarının belirlenmesi aşamalarından oluşmaktadır. Araştırma alanına ait en uygun alan kullanım haritası, çevre düzeni planı ve mevcut alan kullanımları karşılaştırılarak çelişki alanları belirlenmiştir. Dördüncü bölüm ise, geliştirilmiş en uygun alan kullanım haritasının oluşturulması, köy gelişme ve yeni yerleşim alanlarının belirlenmesi ve İslamköy örneğinde ekolojik blok planlaması modeli oluşturulması alt başlıklarından oluşmaktadir.

\section{BULGULAR VE TARTIŞMA}

\section{Araştırma Alanının Potansiyel Kullanımlara Uygun- luğu}

Araştırma alanının potansiyel kullanımlara uygunluğunun belirlenmesinde, alanın doğal ve sosyo-kültürel yapısının analizinden elde edilen veriler, ekolojik temellere dayanan bir planlama yöntemi çerçevesinde değerlendirilmeye çalışımıştır. Araştırma alanının ayrıntılı bir envanterinin çıkarılması sonucunda alandaki potansiyel kullanımlar; tarım, çayır-mera, orman, yerleşim, rekreasyon ve sanayi olarak belirlenmiştir. Araştırma alanında potansiyel tarım alanlarının saptanması için yapılan analiz sonuçlarına göre alanın \%41'i (6263 ha) I. derecede uygun, \%27'si (4120 ha) II. derecede uygun, \%14,7'si (2244 ha) III. derecede uygun, \%17,3'ü (2623 ha) IV. derecede uygun olarak belirlenmiştir. Potansiyel tarım alanları incelendiğinde I. derecede uygun alanlar, araştırma alanının alüvyal topraklarını içine alan bölümdür. $\mathrm{Bu}$ alanlar toprak yetenek sınıfı açısından I. ve II. sınıf toprakların bulunduğu ve eğimin genel olarak \%0-2 ile \%2-6 arasında değiştiği tarım alanlarıdır. Araştırma alanına ait potansiyel tarım alanları Şekil 3'te verilmiştir. Alan kullanım planları ve politikaları ülkemizde tam anlamıyla uygulanamamaktadır. Bunun sonucu eğimli, verimsiz, sığ topraklı alanlar tarım alanı olarak kullanılırken yanlış kararlar sonucu, I. sınıf tarım toprakları üzerinde yapılan imar planları ile yerleşim alanları ve sanayi kuruluşlarına yer verilmekte, doğal kaynaklarımız geri dönüşü mümkün olmayan kullanımlar ile yok olmaktadır (Konaklı, 2011). Bu nedenle ülkemizde alan kullanımına ilişkin kararlarının doğal kaynak envanterine dayalı olarak yapılan alan kullanım planlaması çalışmaları sonuçlarına göre alınması ve uygulanması zorunluluğu ortaya çıkmaktadır.

Araştırma alanın da potansiyel çayır-mera alanları için yapılan analiz sonuçlarına göre alanın $\% 5,9$ 'u (885 ha) I. derecede uygun, \%52,9'u (8065 ha) II. derecede uygun, $\% 16,5$ 'i (2525 ha) III. derecede uygun, \%24,7'si (3775 ha) VI. derecede uygun alanlar olarak belirlenmiştir. Potansiyel çayır-mera alanlarının daha çok III. ve IV. sınıf arazilerde, eğimin \%2-6 arasında yer aldığı alanlarda 
dağılım gösterdiği izlenmektedir. Araştırma alanına ait potansiyel çayır-mera alanları Şekil 3'te verilmiştir.
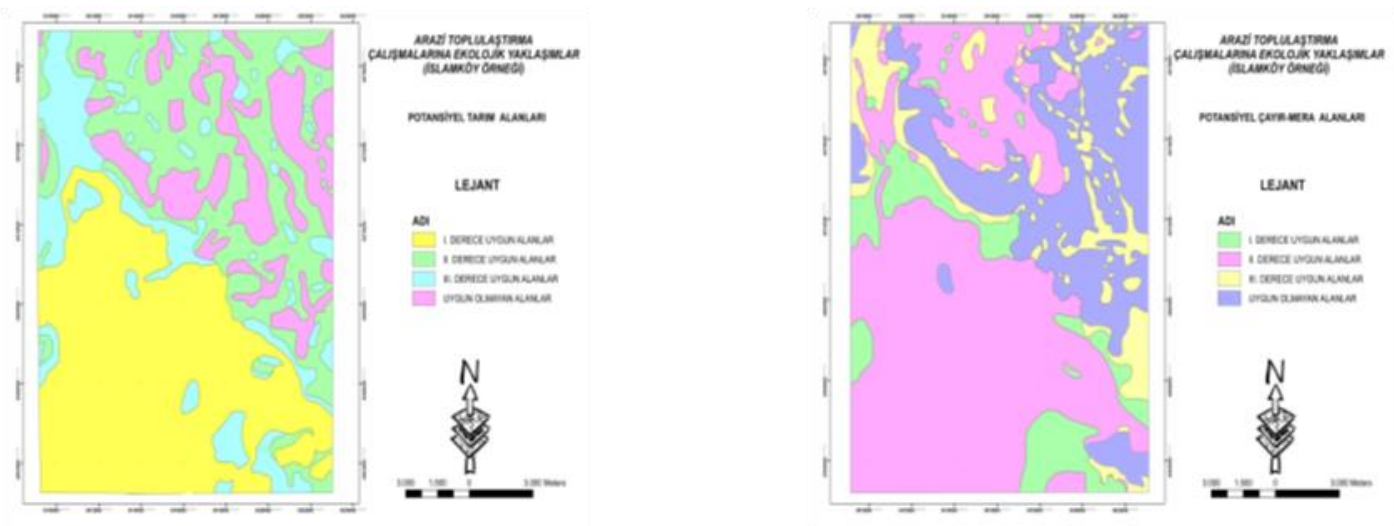

Şekil 3. Araştırma alanına ait potansiyel tarım ve çayır-mera alanları alanları

Araştırma alanında potansiyel orman alanları için yapılan analiz sonuçlarına göre alanın \%23'ü (3508 ha) I. derecede uygun, \% 22,6'sI (3458 ha) II. derecede uygun, $\% 40,4$ 'ü (6159 ha) III. derecede uygun, \%14'ü (2125 ha) VI. derecede uygun alanlar olarak belirlenmiştir. Potansiyel orman alanlarının daha çok VI. ve VII. sınıf arazilerde, eğimin \%12'den fazla olduğu alanlar arasında, tahrip olmuş maki alanlarında ve orman toprağı olarak nitelendirilen çıplak alanlarda dağılım gösterdiği izlenmektedir (Şekil 4). Araştırma alanında potansiyel yerleşim alanları için yapılan analiz sonuçlarına göre alanın $\% 8,3$ 'ü (1279 ha) I. derecede uygun, \%37,4'ü (5722 ha) II. derecede uygun, \%41,7'si (6325 ha) III. derecede uygun, \%12,6'sı (1924 ha) VI. derecede uygun alanlar olarak belirlenmiştir. Potansiyel yerleşim alanlarının daha çok VII. sınıf arazilerde, eğimin \%6-12 olduğu alanlar arasında dağılım gösterdiği izlenmektedir (Şekil 4). Po-

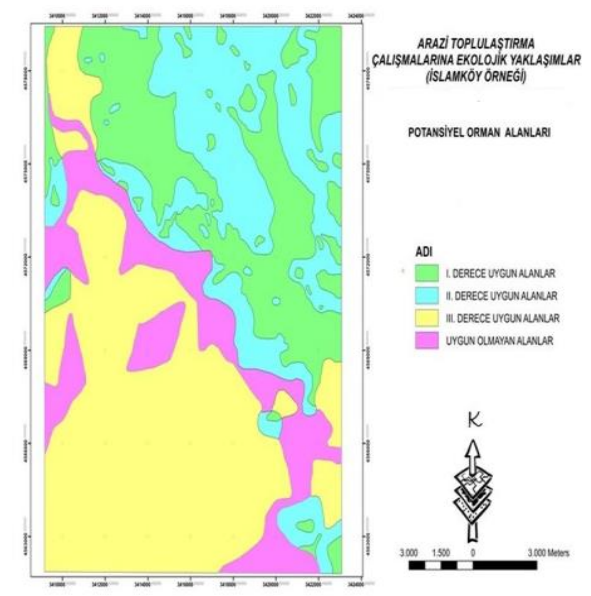

tansiyel rekreasyon alanları için yapılan analiz sonuçlarına göre alanın\%17,48'i (2665 ha) I.derecede uygun, $\% 34,87$ 'si (5318 ha) II. derecede uygun,\%45,7'si (6969 ha) III. derecede uygun, \%1,95'i (296 ha) VI. derecede uygun alanlar olarak belirlenmiştir. Potansiyel rekreasyon alanlarının daha çok VII. sınıf arazilerde, eğimin \%612 olduğu alanlar arasında ve su kaynaklarına yakın alanlarda dağılım gösterdiği izlenmektedir (Şekil 5).

Potansiyel sanayi alanları için yapılan analiz sonuçlarına göre alanın \%8,45'i (1292 ha) I. derecede uygun, $\% 54,72$ 'si (8322 ha) II. derecede uygun, \%32,78'i (4997 ha) III. derecede uygun, $\% 4,05$ 'i (618 ha) VI. derecede uygun alanlar olarak belirlenmiştir. Potansiyel sanayi alanlarının daha çok VII. sınıf arazilerde eğimin \%6-12 olduğu alanlar arasında dağılım gösterdiği izlenmektedir (Şekil 5).

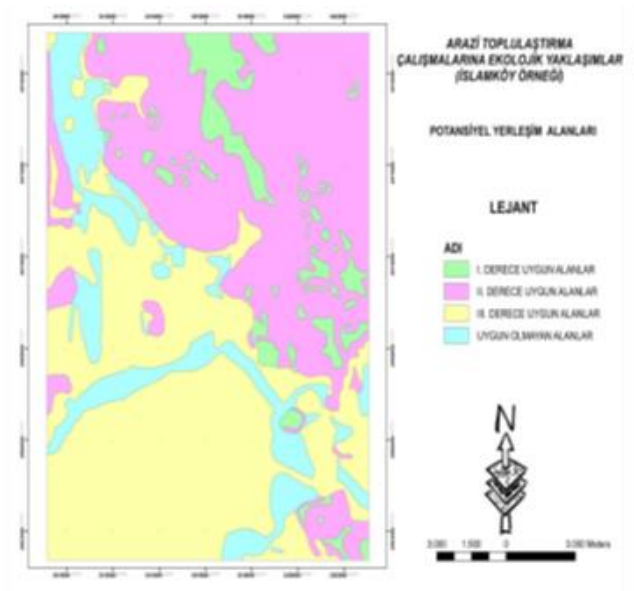

Şekil 4. Araştırma alanına ait potansiyel orman ve yerleşim alanları 

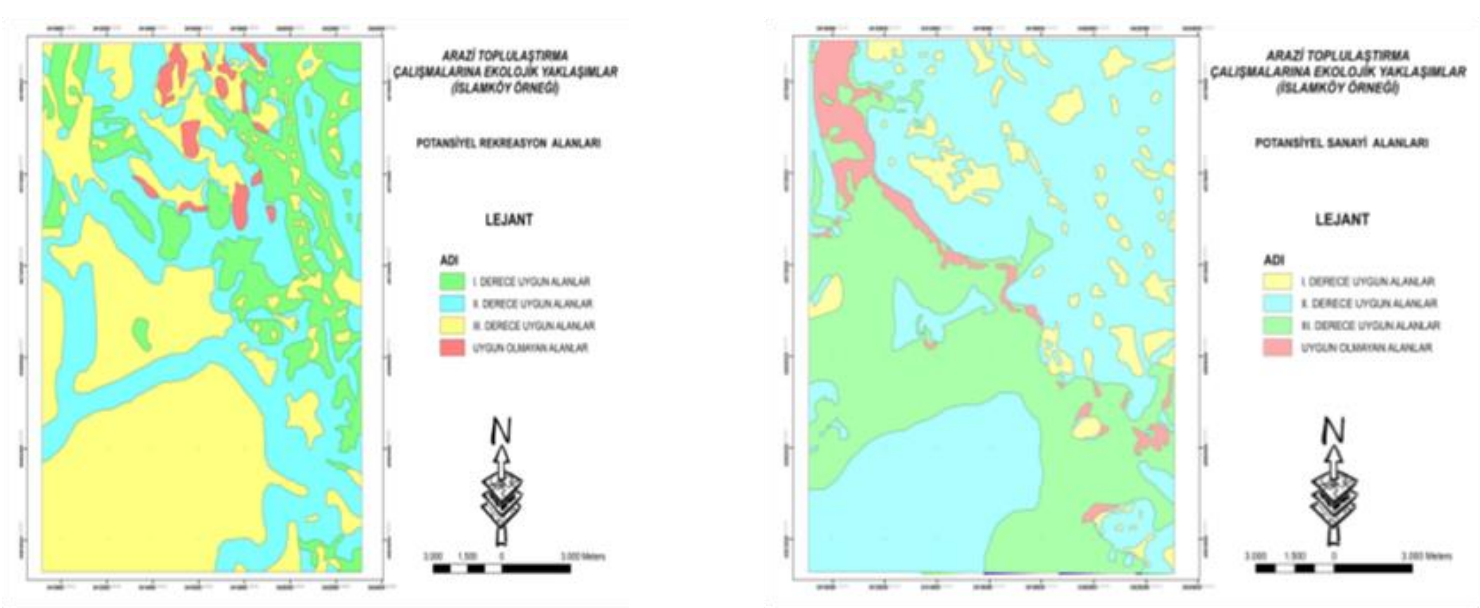

Şekil 5. Araştırma alanına ait potansiyel rekreasyon ve sanayi alanları

\section{Araştırma Alanının Optimal Alan Kullanımı}

Araştırma alanında alan kullanımları ekolojik ve ekonomik ölçütler gözetilerek tarım, orman, çayır-mera, rekreasyon, yerleşim ve sanayi kullanımları olarak sınıflandırılmıştır. Yöntemde açıklandığı gibi "Su Kirliliği Kontrol Yönetmeliği"ne göre bağlı kalınarak nehir ve akarsularda koruma zonları oluşturulmuş ve puanlama yapılmıştır. Araştırma alanında mera alanlarının bulunmaması ve hayvancılık faaliyetlerinin yapılıyor olması mera alanlarının önemini oldukça artırmıştır. Bu nedenle optimal alan kullanım haritası oluşturulurken, çalışma yöntemine bağı kalacak şekilde ve araştırma alanındaki ekonomik faaliyetler gözetilerek aynı etki derecesine sahip alanlarda öncelik mera alanlarına verilmiştir. Arazi kullanım planlamasında herhangi bir alan birden fazla sayıda kullanım tipi için uygun olabilmektedir. Öte yandan kullanım tipleri birbirleri ile rekabet halindedir. Eğer alanı kullanan kullanım tipleri önemli oranda birbirleri ile rekabet halinde ise o takdirde bu kullanım tipleri potansiyel çatışma kaynakları olacaktır. Bu mekânsal çatışmaların önüne geçilebilmesi için çatışan kullanım tiplerinin en uygun kullanım tipi için ayrılması gerekmektedir (Konaklı, 2011).

$\mathrm{Bu}$ amaçla, sorgulamalar sonucunda tarım, orman, çayır-mera, rekreasyon, yerleşim ve sanayi alan kullanım tipileri içerisinden en uygun alan kullanımı elde edilemediğinde meydana gelen boş alanlar mevcut alan kullanımı da dikkate alınarak önce ekolojik uygunluk derecesi 1. derece uygun olan alanlar sonra 2. derece uygun olan alanlar değerlendirmeye alınmıştır. Araştırma alanına ait en uygun alan kullanımları Şekil 6'da verilmiştir.

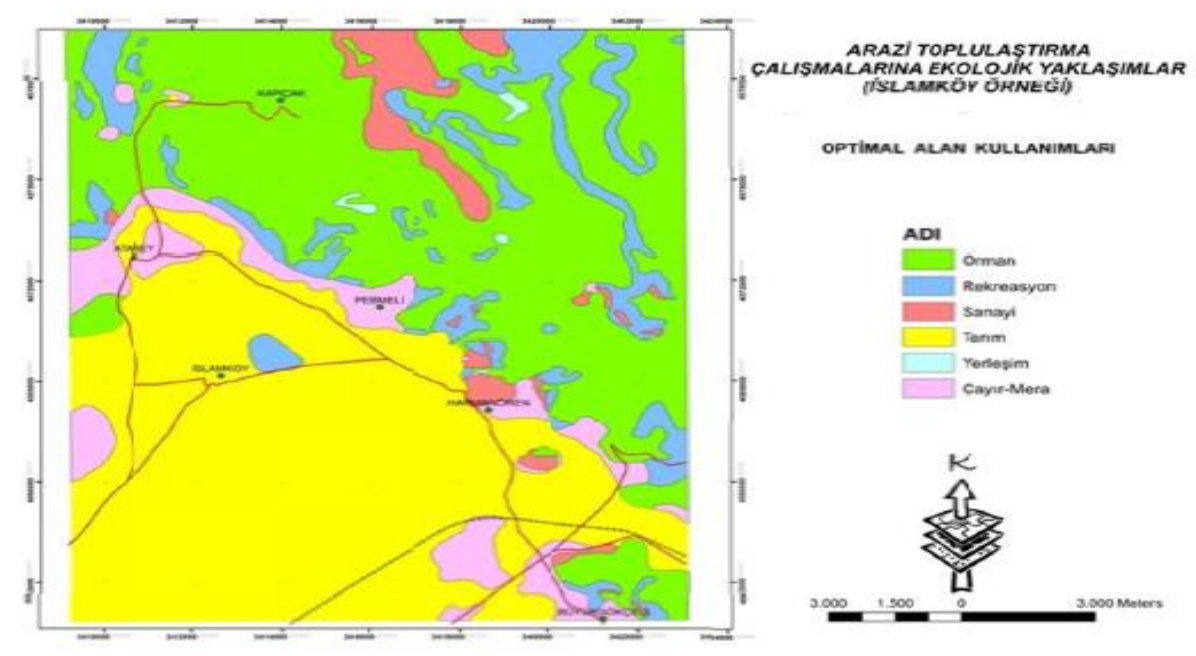

Şekil 6. Araştırma alanına ait optimal alan kullanımları 


\section{Mevcut Alan Kullanımları, Çevre Düzeni Planı ve Op- timal Alan Kullanım Haritası Karşılaştırması}

Araştırma alanı içerisinde kalan İslamköy idari sınırları $37^{\circ} 95^{\prime}$ ve $37^{\circ} 91^{\prime}$ Kuzey paralelleri ile $30^{\circ} 64^{\prime}$ ve $30^{\circ} 70^{\prime}$ Doğu meridyenleri içerisinde yer alan 1303 ha'lık alanı kapsamaktadır. İslamköy mevcut köy yerleşim alanı 54,50 ha ile toplam alanın $\% 4,18$ 'lik kısmını oluşturmaktadır. İslamköy idari sınırları içerisinde orman alanları 31,44 ha ile $\% 2,41$ 'lik kısmını, rekreasyon alanları 8,17 ha ile $\% 6,2$ 'lik kısmını, fundalık alanlar 109,96 ha ile
$\% 8,43^{\prime}$ lük kısmını, tarım alanları 1098,93 ha ile $\% 84,33$ 'lük kısmını oluşturmaktadır.

T.C. Çevre ve Şehircilik Bakanlığı Mekansal Planlama Genel Müdürlüğü tarafından hazırlanan Antalya-BurdurIsparta Planlama Bölgesi 1/100000 ölçekli çevre düzeni planı incelendiğinde (Şekil 7) İslamköy beldesinde sulamalı tarım alanı 952,3 ha ile \%73,0 lük kısmını, orman alanları 143 ha ile \%11'lik kısmını, büyük kentsel yeşil alan 62,4 ha ile $\% 4,8$ 'lik kısmını, kentsel yerleşim alanı 54,5 ha ile $\% 4,18$ 'lik kısmını, kentsel gelişim alanı 90,8 ha alan ile \%6,97'lik kısmını oluşturmaktadır.

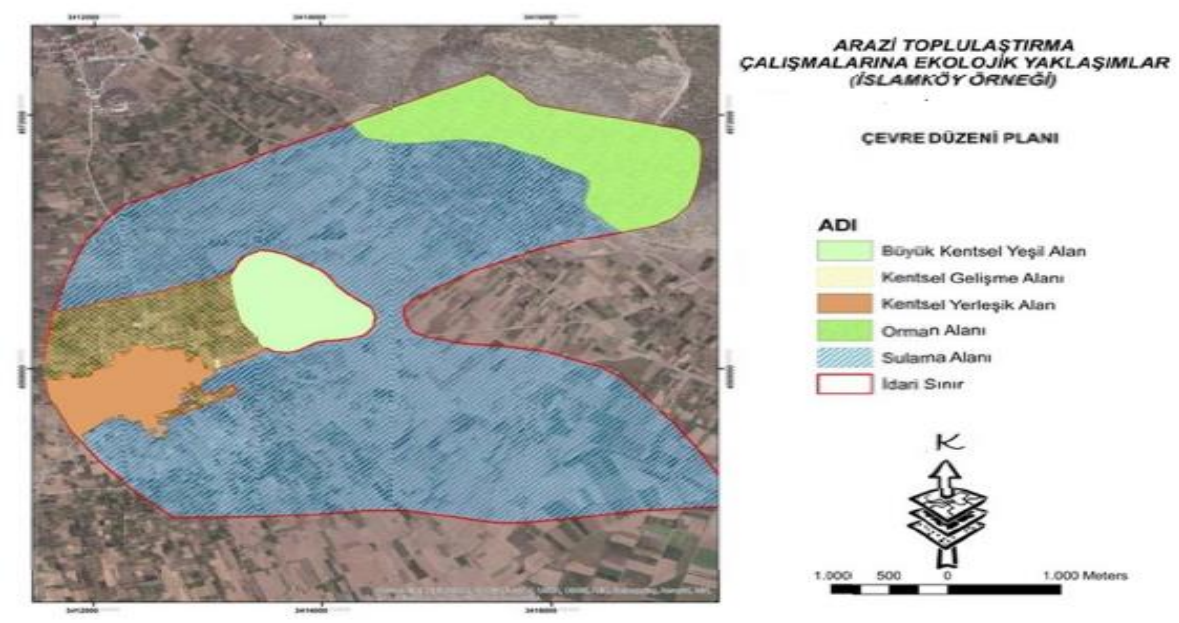

Şekil 7. İslamköy çevre düzeni planı

İslamköy alan kullanım haritası incelendiğinde (Şekil 8) tarım alanı 10432 ha ile \%80'lik kısmını, orman alanları 34,9 ha ile $\% 2,67$ 'lik kısmını, rekreasyon alanı 85,3 ha ile \%6,54'lük kısmını, çayır-mera alanı 139,6 ha ile $\% 10,71$ 'lik kısmını oluşturmaktadır.

Halihazır harita, çevre düzeni planı ve en uygun alan kullanım haritası karşılaştırıldığında İslamköy topraklarının $\% 80$ lik büyük bir kısmı tarım kullanımı için 1. derece uygun olan topraklardan meydana gelmektedir. Bu bağlamda İslamköy beldesinde en uygun alan kullanımları ile mevcut alan kullanımları ve çevre düzeni planında sulama alanı olarak belirlenen alanlar orman ve tarım alan kullanımı için paralellik gösterdiği; yerleşim, sanayi ve çayır-mera kullanımı için paralellik göstermediği görülmektedir. Rekreasyon alan kullanımı çevre düzeni planı ve en uygun alan kullanım haritasında paralellik göstermektedir, ancak mevcut alan kullanımında rekreasyon amacına hizmet etmediği belirlenmiştir. 


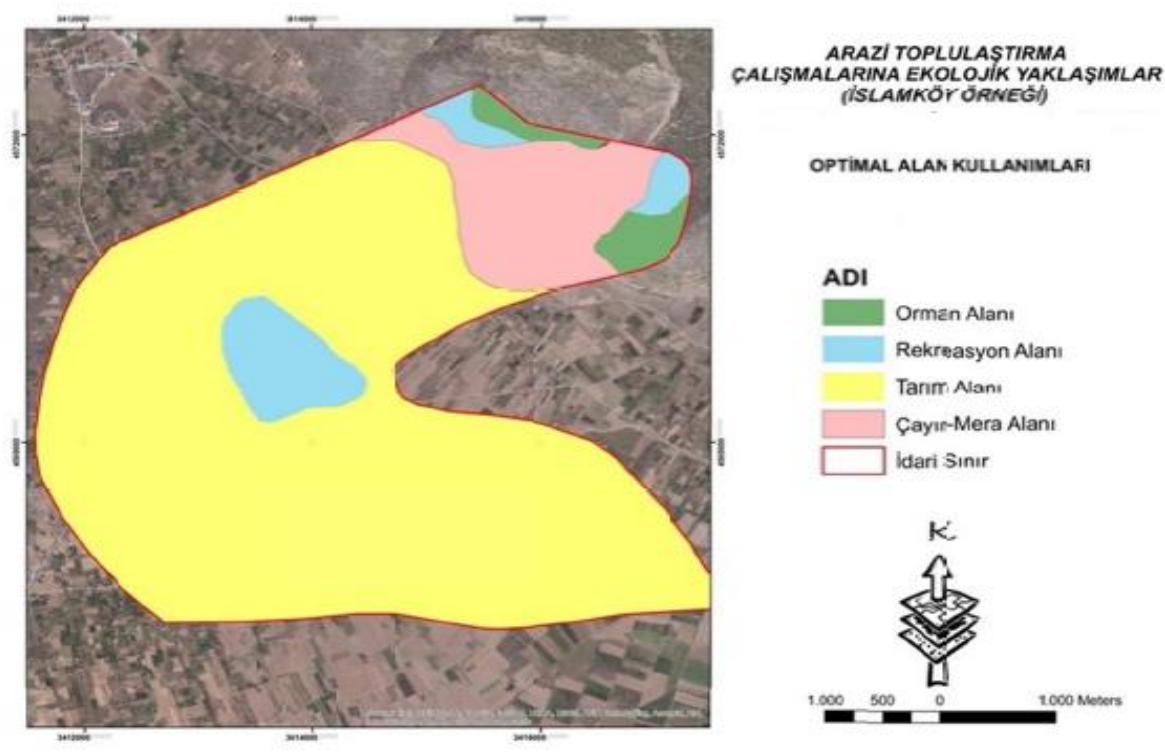

Şekil 8. İslamköy optimal alan kullanım haritası

\section{Geliştirilmiş Optimal Alan Kullanım Haritası ve Eko- Iojik Arazi Toplulaştırma Modeli}

Geliştirilmiş en uygun alan kullanım haritasının oluşturulması kapsamında köy gelişim ve yeni yerleşim alan- larının tespiti yapılmış olup (Şekil 9) mevcut kadastro durumu göz önüne alınarak geliştirilmiş en uygun alan kullanım haritası oluşturulmuştur (Şekil 9).
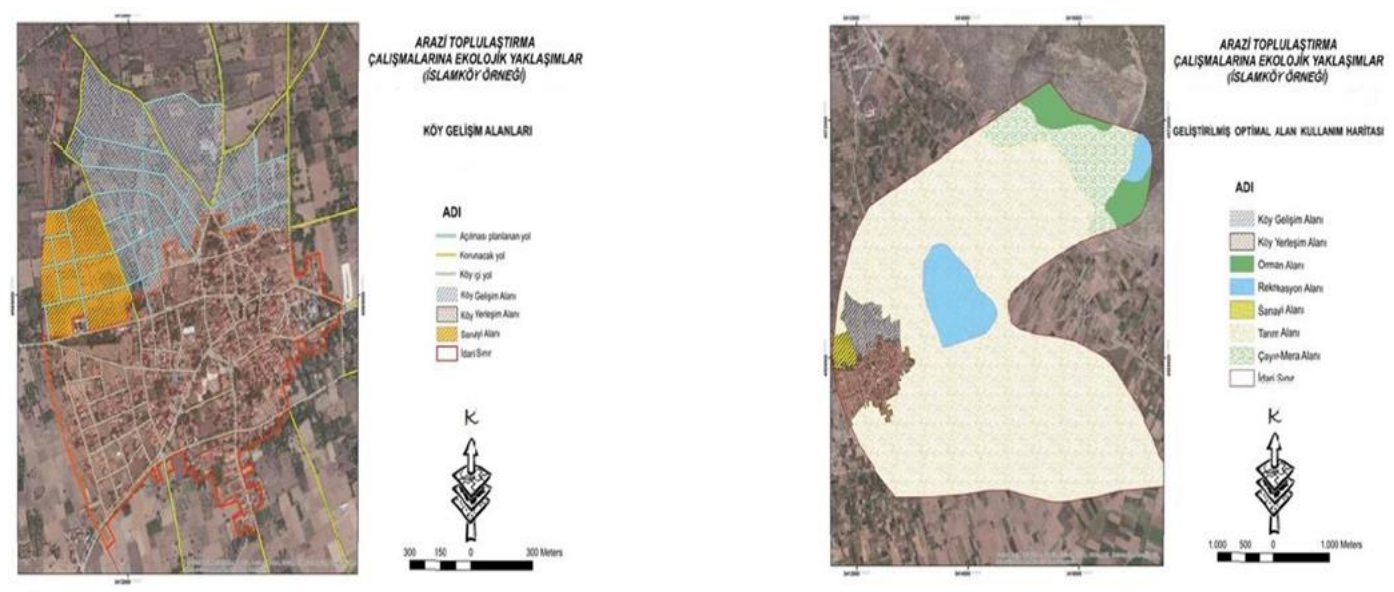

Şekil 9. İslamköy yerleşim ve gelişim alanları ile geliştirilmiş optimal alan kullanımı

Ülkemizde köy yerleşim alanlarının tespiti çalışmalarında vali; ilgili ilçe kaymakamının görüşlerini de dikkate alarak, köy yerleşme alanını tespiti ve köy yerleşme alanı planını hazırlamak üzere vali yardımcısı başkanlığında; Milli Emlak Müdürlüğü, Çevre ve Şehircilik Müdürlüğü, ilgili Kadastro Müdürlüğü, İl Gıda Tarım ve Hayvancılık müdürlüğü ve İI Özel İdaresinden birer teknik eleman ile köy temsilcilerinden oluşan bir komisyonu görevlendirmektedir. Vali oluru ile görevlendirilen komisyon ilk aşamada köye ait harita, köyün sosyo-ekonomik ya- pısını gösteren belge, doküman ve gerekli diğer envanterleri derledikten sonra ön değerlendirmeler yapılmaktadır. İkinci aşamada ise köy mahalline gidilerek köyün gelecekteki gelişme durumu tespit edilerek intiyaç duyulan konut parsel sayısı ve büyüklükleri, sosyal tesisler için tahsis edilecek arazi ve köy yerleşme alanının miktarı hesaplanmaktadır. Mevcut köy yerleşim alanı ile bütünlük teşkil edecek şekilde ve mümkün olduğunca verimi düşük, mera niteliğini kaybetmiş ve tarım dışı olarak kullanılan hazine arazilerine öncelik vererek gelişme 
alanı için uygunluğuna karar verdiği sahanın sınırları komisyon tarafından belirlenmektedir. Köy yerleşim haritaları 2010/22 sayılı genelgede; 442 sayılı Köy Kanununa ek 3367sayılı Kanun ve Köy Yerleşme Alanı Uygulama Yönetmeliği'ne göre yapılan haritalardır. İslamköy idari sınırlarında korunması gerekli yollar tespit edilmiş çiftçi- lerin parsellerine ulaşmalarında hak kayıpları yaşanmaması amacıyla yeni tarla içi yollar planlanmıştır. Ayrıca korunması gerekli doğal alanlar belirlenerek tarım, rekreasyon, çayır-mera ve sanayi kullanımları için öneriler geliştirilmiştir (Şekil 10).

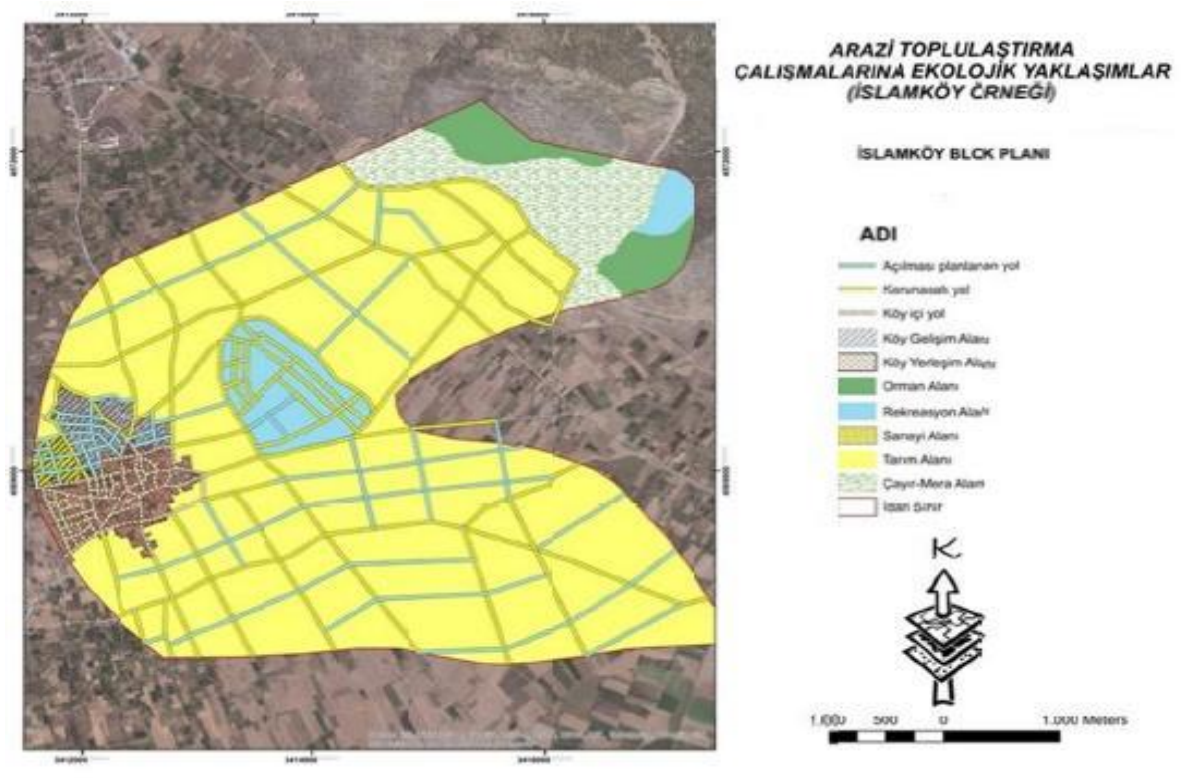

Şekil 10. İslamköy blok planı

\section{SONUÇ VE ÖNERILER}

OECD ülkeleri arasında tarımsal işletmeleri giderek küçülen tek ülke konumunda kalan Türkiye'de, toplam nüfusun önemli bir bölümünün yaşadığı kırsal alanlarda, miras yoluyla parçalanma ve hisselerin bölünerek satılması gibi sebeplerle giderek küçülen tarımsal işletmeler ekonomik özelliklerini kaybetmekte buna bağlı olarak kentsel alanlara göç olayları artmaktadır. Bu kapsamda söz konusu parçalanmayı önleyecek, göç olaylarını azaltacak ve kırsal alanlarda yaşam koşullarını iyileştirecek birtakım düzenlemelerin yapılması gerekliliği ortaya çıkmaktadır. Bakanlar Kurulu Kararı ile Uygulama Alanı olarak ilan edilen yerlerde, 3083 Sayılı Sulama Alanlarında Arazi Düzenlenmesine Dair Tarım Reformu Kanunu'na göre arazi kullanım planlaması yapılması gerekmektedir. 3083 Sayılı Kanun'un Uygulama Yönetmeliği'nde "Araziye yönelik kullanım talepleri dikkate alınarak, arazinin en uygun kullanım şekillerini alternatifleri ile birlikte sunmak suretiyle, araziyi kullananlar arasında talep ve menfaat çatışmalarından kaynaklanan problemleri asgariye indirmek ve arazinin özelliklerine uygun ideal kullanım şekillerini belirlemektir." denilerek Tarım Arazileri Değerlendirme Daire Başkanlığı tarafından koordine edilen arazi kullanım planlarının koruma-kullanma dengesini gözeterek oluşturulması gerektiği ifade edilmiştir. Türkiye'de alan kullanımı ile ilgili olarak karşı- laşılan sorunların başında, özellikle planlama aşamasında hangi alanın hangi amaçla kullanılacağı ve hangi kullanımların yer alacağı ile ilgili bilimsel ve teknik ölçütlerin dikkate alınmadan planlanması gelmektedir. Alan uygunluk değerlendirmeleri ve alan kullanım planlaması çözümlemelerinde, doğal kaynakların korunmasını sağlayacak en uygun alan kullanımı için ölçütlerin belirlenmesi gerekmektedir. Yanlış arazi kullanımının önlenmesi ve kırsal alan iyileştirme çalışmalarında ki başarı geniş kapsamlı ve multidisipliner bir planlamaya bağlıdır. Bu iyileştirmeler, tarım potansiyeli yüksek olan toprakların tarımsal işlevlerini birincil olarak ele alan planlamalar yapılması, tarımsal hammaddeye dayalı sanayi alanlarının planlanması, doğal alanların oluşturulması ve mevcut doğal alanların korunması için önlemlerin alınması, kırsal yerleşimlerde yaşam kalitesini artıracak rekreasyonel alanların planlanması, köy içi yenileme çalışmalarının yapılması ve köy gelişim alanlarının planlanması gibi unsurları içeren çok yönlü bir planlama yaklaşımı ile gerçekleştirilebilir. Kırsal alanlarda gelişmişliğin arttırılabilmesi için, kırsal kesimde yaşamlarını sürdüren kişilerin hayat standartlarının yükseltilmesinin yanında, kırsal kesimdeki yapısal sorunların da giderilmesine gereksinim vardır. Ülkemizde de acilen arazi parçalanmasının önüne geçecek kurumsal ve yasal düzenlemeler yapılarak yenilenemeyen doğal kaynaklarımızdan olan toprakların amaç dışı kullanımının önünde geçilmelidir. Türkiye'de kırsal alanlarda su kaynakları, ormanlar, yaylalar 
vb. zengin doğal kaynaklar; kentleşme, endüstrileşme, madencilik faaliyetleri, meraların aşırı otlatılması, tarıma elverişli olmayan alanların tarım kullanımına açılması kalkınma, turizm vb. birtakım ekonomik kaygılar ile tahrip edilmekte ve bir daha geri dönüşü olmayacak biçimde yok olma tehlikesi ile karşı karşıya bırakılmaktadır. Ülkemizde doğal kaynakların zenginliğine karşın söz konusu faaliyetlerin bilinçsizce yürütülmesi ve olumsuz doğa koşulları sonucunda pek çok sorunla karşılaşılmakta ve karşılaşılan sorunlara çözüm önerileri getirme intiyacı doğmuştur. Kırsal peyzaj planlama çalışmalarında kentsel ve kırsal geçişlerinde, çeşitli alan kullanımları arasında ve ekolojik açıdan önemli doğal kaynakların çevrelerinde yeşil kuşak çalışmaları ile tampon bölgeler oluşturulmalıdır. Kırsal ya da kentsel yerleşmelerin bulunduğu alanlarda daha sık görülen yanlış arazi kullanımları için yerel, bölgesel ve ülkesel ölçekte optimal alan kullanımlarını içeren peyzaj planları hazırlanmalı yapılacak olan yatırımlarda veya plan kararlarında ekolojik altık olarak dikkate alınmalıdır.

Sanayi sektöründe yer alan yatırımcı ve çalışanlar için atıkların en aza indirilmesiyle geri kazanımı konusunda ekolojik farkındalık yaratacak periyodik eğitim seminerleri ve kontroller gerçekleştirilmelidir.

Sürdürülebilir bir endüstri politikası uygulanmalı ve sağlam bir yasal zemin oluşturulmalıdır. Çevre kirliliğine neden olduğu tespit edilen tarımsal üretimin önlenmesi amacıyla gıda sektöründe ki üretimin terk edilip süs bitkisi, endüstriyel ağaç üretimi, rulo çim üretimi gibi ekonomik getirisi yüksek farklı ürünlerin üretilmesi konusunda gerekli pazar ve özendirme çalışmaları yapılmalıdir.

Ormanlara yönelik kamu kuruluşları, özel sektör, sivil toplum kuruluşları ve vakıflar tarafından düzenlenen aktiviteler desteklenmeli orman azalması, çölleşme, sel, çığ, erozyon gibi olumsuz durumları önleyecek ağaçlandırma çalışmaları ve bilinçlendirme kampanyaları teşvik edilmelidir.

Kırsal alanlarda yapılan planlama çalışmalarında karayolları, demiryolları, sulama kanalları, arazi toplulaştırması, amenajman çalışmaları, doğa koruma ve rekreasyon çalışmaları ile birlikte koruma-kullanma ilkesi gözetilerek yürütülmelidir. Köy yerleşik alanının dışında kalan alanlara altyapı, temizlik gibi hizmetlerin ulaştırılmasında yaşanan güçlükler nedeni ile yapılaşma izinleri verilmemelidir.

Arazi toplulaştırma çalışmaları sırasında peyzaj planları, blok ve parsel planlarına ekolojik altlık olarak kullanılmalı; proje sahasında flora, fauna ve peyzaj değeri yüksek doğal alanların korunması ve geliştirilmesine önem verilmelidir.
Peyzaj planlamada yer alan doğallık, biyoçeşitlilik, nadirlik, tehdit altında olma, yeniden teşhis edilebilirlik ölçütleri göz önünde bulundurularak koruma alanı niteliği taşıyan alanlar belirlenmeli ve mümkün olan en kısa sürede yasal koruma altına alınarak yönetim planları hazırlanmalıdır.

Yapılan çalışma sonucunda, doğal kaynakların korunması için ülkesel ölçekte ekolojik master planlarının, havza yönetim planlarının ve peyzaj planlarının hazırlanmasının gerekliliği ortaya çıkmıştır. Planlama alanındaki kamu kuruluşları, ilgili sektörler, yerel kurumlar, yerel yönetimlerin iş birliği içerisinde arazi tahsisi çalışmalarını gerçekleştirmelidir.

\section{TEŞEKKÜR}

Bu çalışma, "Arazi Toplulaştırma Çalışmalarına Ekolojik Yaklaşımlar 'Isparta-İlamköy Örneği”" başlıklı yüksek lisans tez verileri kullanılarak hazırlanmıştır. Yüksek lisans tezine katkılarından dolayı Prof. Dr. Mehmet TOPAY'a teşekkür ederiz.

\section{KAYNAKLAR}

Auweck, F.A. (1993). Landliche Endwicklung und Landschaftsentwicklung, Deutscher Verein Für Vermessungwesen (DVW), Landesverein Bayern E.V. Mitteilungsblatt, 1:15-31.

Başal, M. (1998). Doğalgaz-Yapracık Tesisleri Alan Kullanım Planlaması. Ankara Üniversitesi Ziraat Fakültesi Yayınları, Ankara.

Başyiğit, L. (1996). Isparta-Atabey Civarı Topraklarının Etüdü ve Haritalanması. Selçuk Üniversitesi, Fen Bilimleri Enstitüsü, Yüksek Lisans Tezi, Konya.

Boztoprak, T., Demir, O., Çoruhlu, Y. E. (2016). Comparison of Expropriation and Land Consolidation on the Regulation of Agricultural Land. Sigma Journal Engineering and Natural Sciences, 34(1): 43-55.

Durduran, S.S., Cora, T., Bozdağ, A., Okka, C. T. (2018). Konya İli Topraklık Mahallesi Arazi Toplulaştırma Uygulamasının Mekansal ve İşlevsel Olarak Değerlendirilmesi, Ömer Halisdemir Üniversitesi Mühendislik Bilimleri Dergisi, 7(2):661-671.

Isparta Valiliği, (2020). Atabey. http://www.isparta.gov.tr/atabey (Erişim Tarihi: 17.05.2020)

Kınalı, T. (2015). Arazi Toplulaştırma Çalışmalarına Ekolojik Yaklaşımlar 'Isparta-İslamköy Örneği'. Süleyman Demirel Üniversitesi, Fen Bilimleri Enstitüsü, Yüksek Lisans Tezi, Isparta.

Konaklı, N. (2011). Konya Altınapa Baraj Gölü Havzası Örneğinde Optimal Alan Kullanım Planının Belirlenmesi. Çukurova Üniversitesi, Fen Bilimleri Enstitüsü, Doktora Tezi, Adana.

McHarg, I. (1971). Man, Planetary Disease. The 1971 B. Y. Morrison Memorial Lecture, $33 \mathrm{pg}$.

Ortaçeşme, V. (1996). Adana İli Akdeniz Kıyı Kesiminin Ekolojik Peyzaj Planlama İlkeleri Çerçevesinde Değerlendirilme 
ve Optimal Alan Kullanım Önerileri. Çukurova Üniversitesi, Fen Bilimleri Enstitüsü, Doktora Tezi, Adana.

Patrono, A. (1998). Multi-Criteria Analysis and Geographic Information Systems: Analysis of Natural Areas and Ecological Distributions. Multicriteria Analysis for Land-Use Management, Edited by Euro Beinat and Peter Nijkamp, Kluwer Academic Publishers, Dordrecht, Netherlands.

Sönmezyıldız, E. (2012). Eskişehir Beyazaltın Köyü Arazi TopIulaştırma Alanında Sulama Performansının Değerlendirilmesi. Ankara Üniversitesi, Fen Bilimleri Enstitüsü, Yüksek Lisans Tezi, Ankara.

Steiner, F. (1999). Living Landscape: An Ecological Approach to Landscape Planning, McGraw-Hill Publishing, Arizona.
Tozar, T. (2006). Doğal Kaynakların Sürdürülebilirliği İçin Geliştirilen Ekolojik Planlama Yöntemleri. Yıldız Teknik Üniversitesi, Fen Bilimleri Enstitüsü, Yüksek Lisans Tezi, İstanbul.

URL-1 (2020). Atabey Nüfus Verileri. https://www.nufusune.com/atabey-ilce-nufusu-isparta (Erişim Tarihi: 17.05.2020)

URL-2 (2014). Araştırma Alanında Meyve Ağaçları. ispartaprovince.blogspot.com.tr/p/atabey.html (Erişim Tarihi: 20.05.2014).

URL-3 (2014). Atabey İlçesi Tarım Alanları Dağılımı. isparta.tarim.gov.tr/atabey.html (Erişim Tarihi: 20.05.2014).

Yılmaz, E. (2006). Bir Arazi Kullanım Planlaması Modeli: Cehennemdere Vadisi Örneği. Doğu Akdeniz Ormancılık Araştırma Enstitüsü Yayınları, Mersin. 